\title{
Destination Attributes Affecting Tourists' Readiness to Recommend Lagos State (Nigeria) for Tourism
}

\section{J C Madu}

Architect and Urban and Regional Planner, Vienna

\section{S N Madu}

Department of Psychology, University of the North

\section{ABSTRACT}

This is an investigation into tourists* readiness to recommend Lagos State of Nigeria as a tourist destination and the destination attributes (factors) affecting their readiness. The investigation was conducted through a survey of 378 on-site business, recreational, international and domestic tourists sampled from different tourist attraction sites. Results show that the majority of the tourists were ready to recommend the destination. However, more recreational tourists are ready to recommend the destination than the business tourists. More domestic tourists are also ready to recommend the destination than the international tourists. The authors conclude that there is an urgent need for tourism encouraging measures aimed at maximisation of the potentials of hospitality, and minimisation of maintenance of tourist infrastructures and transportation problems; and increased measures to guarantee personal safety in the State.

JEL Z00

\section{INTRODUCTION}

In contemporary business development and management, organisations tend to engage in studies that explore the needs and experiences of their customers. This is because improvement of customer satisfaction became one of the major challenges facing business establishments in the 1990s (Barsky \& Labagh, 1992: 32-40). A customer who is dissatisfied with his/her experience with a product or service is likely to be a lost customer for the organisation responsible for the supply (Bahia \& Paulin, 2000: 27-42). One of the crucial issues in this relationship is that the outcome of the experience is mostly extended to the customer's friends and relatives. Thereby a dissatisfied consumer communicates his/her aggravation to an average of eleven persons, while a satisfied consumer communicates his/her enthusiasm to an average of three persons (Horovitz, 
1990). Demos (1992: 81-86) added as one of the fundamental 'rules of thumb' in the tourism industry management, that one dissatisfied customer has more influence than ten content ones. This influence is a negative one, however, since dissatisfaction sounds louder than satisfaction. The analysis of tourism is a phenomenon in the modern socio-economic development. The identification of its status and problems, and the study of the factors affecting tourists' readiness to recommend the tourism destination makes it possible to formulate the basic characteristics of future policies for planning of tourism in the respective destinations. However, very few studies have been conducted on various aspects of tourism development in the Lagos State of Nigeria, and none has been conducted particularly on their readiness to recommend Lagos State as a tourism destination to others. Hence, the question: what destination attributes affect tourist's readiness to recommend Lagos State as a tourism destination to others?

According to Perterson and Wilson (1992: 61-71), more than 15000 academic and trade articles have been published on customer satisfaction until the early $1990 \mathrm{~s}$. These studies centre on the elicitation of the needs of the customers and the corresponding supplies in form of goods and services to maximise customer satisfaction. The maximisation of consumer satisfaction also maximises the profitability and market share of an organisation and the customer's readiness to recommend it to others. This is supported by a survey conducted by the Juran Institute in 1994, whereby 90 per cent of the top managers of America's largest companies who were interviewed agreed on the immense importance of improving customer satisfaction for their companies' success (Vavra, 1997). Therefore, the quality and success of any service delivery and the likelihood of its being recommended to others, are testified by the satisfaction of the customer and their readiness to recommend it to others (Bahia \& Paulin, 2000: 27-42; Brady, \& Robertson, 2001: 53-61; Disney, 1999; 491-8; Herrmann \& Huber, 2000: 77-97; Lassar, Manolis, \& Winsor, 2000: 181-200; Lee, Lee, \& Yoo, 2000: 217-32; Sureshchandar, Rajendran, \& Kamalanabhan, 2001: 111-25; Zeithaml, Berry, \& Parasuraman, 1996: 31-46).

As Barlow and Moller (1996) suggested, "a complaint is a gift from the customer to the establishment". These relationships show the extent to which satisfaction or dissatisfaction of a consumer may affect the image of a product, a service or an establishment. This image, in other words, the influence of the information and experiences acquired by the consumers on the supply, extends to both their lifetime and their lifetime values, and also their willingness to recommend the organisation or destination to others (Vavra, 1997).

Lagos State is the former capital city of Nigeria. It is located on the coastal plain of the Atlantic Ocean stretching 180 kilometres along the Bight of Benin. The area is 3,577 square kilometres, with a population of $5,685,781$ people in 1991 . 
Its State is endowed with tourist attractions and resources that include natural (water based), cultural and historical, and commercial attractions. In spite of these potentials, there are few traces of viable development in the tourism sector. One of the major reasons is that, during the past three decades, Lagos State has experienced an unplanned rapid urbanisation, coupled with the effects of the civil war in the late 1960s. These have had a series of negative impacts (for example, safety problems) on the development of the State in general and particularly in the area of tourism. Some authors (e.g., Ajayi, 1998; Balogun, 1986) refer to Lagos State as a jungle; a horrible and unhealthy city. This is the result of urban planning and management problems, especially in some important areas such as transportation, security, cost of living, etc. This situation is worsened by the general economic instability in the country and the associated social problems. Smoltczyk (1997) described Lagos as the largest city of black Africa with no refuse disposal, no public transport and no mayor; there is no law and order, but is controlled by the street gangsters known as the 'area boys'; and it is a jungle governed by the practice of 'survival of the fittest'. Although this description seems exaggerated and unreliable, Lagos State however seems to emit a feeling of insecurity to its inhabitants. Such problems without doubt would negatively influence the experience of the tourists in this destination as well as their readiness to recommend Lagos State as a tourism destination to others.

Moreover, according to Odutayo (1986), Olukoya (1989), Ukpanah (1990), and Adepeju (1990), there has been also little recognition of tourism as a positive means of improving the economy of the State and nation, despite the tremendous natural, cultural, and commercial attraction resources in the area. In fact, one of the pressing problems facing the State today is the planning and management of the city. A functional and conducive environment should be created to attract more tourists; this will require that the physical or environmental, social, political, psychological, and cultural qualities of the State in particular, and Nigeria in general, are enhanced.

There is a need, therefore, to address the tourism situation in view of the need to diversify the nation's income generating source. As part of this, the Structural Adjustment Programme (SAP) was introduced by the Federal Government of Nigeria in 1986. This programme aims at improving the nation's economic situation in general (Nigerian Economic Review, 1993). In an attempt to implement the SAP by improving tourism, the Lagos State government has enacted a tourism policy that proposes land use zones for the development of tourism activities in 1993. The zones include the Bar beach resort zone, Lekkimaiyegun resort based zone, Kuramo water based tourist complex, Epe marina cultural tourism and recreational zone, Eleko beach, Tarqua bay, and Badagry marine and cultural zone. However, these have not remarkably contributed to an 
improvement of recreational tourism in the State. Such policies do not generally result in improvements unless they guide efforts towards development and unless they are acted upon.

This study hopes to serve as a guideline for tourism planning, and to give direction towards achieving viable and sustainable development in this important economic sector in the State. In fact, proper planning and management based on scientific research can be used to upgrade and revitalise the existing outmoded and under-developed recreational tourism in Lagos State.

\section{METHOD}

\section{Participants}

This study involved the participation of 378 tourists, comprising 229 business tourists (whose main purpose for visiting the Lagos State was business) and 149 holiday (recreational) tourists. (Lagos is a large commercial city in Nigeria. Thus, most visitors to the state are there for business purposes. Among the participants, 223 were domestic tourists and 154 were from abroad. (One tourist failed to indicate where he/she came from). Domestic tourists are all the tourists in Lagos State who came from within Nigeria, but from outside Lagos State. Tourists from abroad or international tourists are those who came from outside Nigeria. 279 were males and 99 were females. 33 ( 8.7 per cent) were within the age range of 12-20 years, 255 (67.5 per cent) were within the age range of 21-40 years, 84 (22.2 per cent) were within the age range of $41-60$ years and 6 (1.6 per cent) were above 60 years of age. They were all non-residents of Lagos State, Nigeria.

\section{Instrument}

A questionnaire used for this study enquires about the purpose of visit to Lagos (business or recreational), and explores tourists' perceptions of the quality of the following destination attributes: personal safety (safety during the day and at night), transportation problems, hospitality, costs (cost of hotel accommodation, meals, drinks, and transportation), and maintenance of tourist infrastructure. They were also asked whether they would recommend Lagos State as a tourist destination to others. Response to the above questions were categorical (e.g., safe/not safe, low/high, yes/no). The last part of the questionnaire contains demographic questions, such as age, gender, nationality and place of work or permanent residence. 
For the coding of the categorical responses to the destination attributes and the readiness to recommend Lagos State as a tourism destination to others, the responses that are negative are coded ' 0 ', and those that are positive are coded ' 1 '.

\section{Procedure}

The spatial extent of the study covers Lagos mainland and its islands. With the assistance of the Lagos State Tourism Board, the major tourist attractions that statistically represent the 'tourist attraction population' in Lagos were selected as sampling locations. Thus, all the major recreational attractions (natural, cultural and historical, and special attractions) were chosen. There were nine recreational attraction sites (Lekki Beach, Bar Beach, Eleko Beach, Tarqua Bay Beach, Whispering Palm, Tinubu Square, National Museum, Apapa Amusement Park, and Badagry Slave Chain) altogether. These attractions were chosen owing to their status as key tourist zones. The business attraction sites were excluded, which means that business tourists and holiday tourists were selected at the same recreational attractions, and at the same time.

\section{Table 1 Locations of survey research and sampling features}

\begin{tabular}{|c|c|c|c|}
\hline $\begin{array}{c}\text { Type of attraction } \\
\text { Sites used for sampling }\end{array}$ & $\begin{array}{c}\text { No of tourists of } \\
\text { 150 sampled } \\
\text { visitors }\end{array}$ & $\begin{array}{c}\text { No of questionn. } \\
\text { filled by } \\
\text { subjects }\end{array}$ & $\begin{array}{c}\text { No of } \\
\text { questionn. } \\
\text { usable }\end{array}$ \\
\hline 1. Natural & & & \\
\hline Lekki Beach & 19 & 79 & 71 \\
\hline Bar Beach & 88 & 75 & 69 \\
\hline Eleko Beach & 81 & 65 & 61 \\
\hline Tarqua Bay & 56 & 47 & 43 \\
\hline Whispering Palm & 22 & 14 & 12 \\
\hline 2. Cultural/historical & & & \\
\hline Tinubi Square & 40 & 25 & 21 \\
\hline National Museum & 54 & 39 & 36 \\
\hline Badagry Slave Chain & 28 & 24 & 21 \\
\hline 3. Special & & & \\
\hline Amusement Park & 58 & 49 & 44 \\
\hline TOTAL & 518 & 417 & 378 \\
\hline
\end{tabular}

\section{RESULTS}

According to the frequency distribution of the tourists' readiness to recommend Lagos State as a tourist destination to others, 149 (65.1 per cent) of the business 
tourists were ready to recommend the destination to others, while 77 (33.6 per cent) were not ready to do so; 3 ( 1.3 per cent) did not respond to the question. In the case of the recreational tourists, 133 (87.9 per cent) of the recreational tourists were ready to recommend the State as a tourism destination to others, while 18 (12.1 per cent) were not. 183 (83.2 per cent) of the domestic tourists were ready to recommend the destination to others, while 37 (16.8 per cent) were not ready to do so; 96 (62.3 per cent of the international tourists were ready to recommend the destination to others, while 58 ( 37.7 per cent) were not.

Table 2 shows the mean scores of the perceptions of the tourists, according to the destination attributes. Operationally, we define an attribute with a mean score that falls above 0.5 (average) to mean either that the attribute has a high value or that it has a low value depending on the coding scale of the attribute.

Table 2 The destination attributes, tourists' mean scores and interpretation

\begin{tabular}{|l|l|l|l|l|}
\hline \multicolumn{1}{|c|}{$\begin{array}{c}\text { Destination } \\
\text { Attributes }\end{array}$} & \multicolumn{1}{|c|}{ Business } & $\begin{array}{c}\text { Recrea- } \\
\text { tional }\end{array}$ & $\begin{array}{c}\text { Interna- } \\
\text { tional }\end{array}$ & Domestic \\
\cline { 2 - 6 }$\left(\begin{array}{c}\text { Mean } \\
\text { (Interpre- } \\
\text { tation) }\end{array}\right.$ & $\begin{array}{c}\text { Mean } \\
\text { (Interpre- } \\
\text { tation) }\end{array}$ & $\begin{array}{c}\text { Mean } \\
\text { (Interpre- } \\
\text { tation) }\end{array}$ & $\begin{array}{c}\text { Mean } \\
\text { Interpre- } \\
\text { tation }\end{array}$ \\
\hline Safety at day time & 0.73 (high) & 0.65 (high) & 0.67 (high) & 0.45 (high) \\
\hline Safety at night & 0.27 (low) & 0.15 (low) & 0.24 (high) & 0.41 (low) \\
\hline $\begin{array}{l}\text { Transportation/ } \\
\text { traffic problems }\end{array}$ & 0.18 (high) & 0.04 (high) & 0.15 (high) & 0.31 (high) \\
\hline Hospitality & 0.58 (high) & 0.07 (low) & 0.58 (high) & 0.48 (low) \\
\hline Cost of hotel & 0.06 (high) & 0.05 (high) & 0.09 (high) & 0.15 (high) \\
\hline Cost of meals & 0.06 (high) & 0.14 (high) & 0.10 (high) & 0.28 (high) \\
\hline Cost of drinks & 0.15 (high) & 0.13 (high) & 0.17 (high) & 0.33 (high) \\
\hline $\begin{array}{l}\text { Cost of } \\
\text { transportation }\end{array}$ & 0.22 (high) & 0.21 (high) & 0.25 (high) & 0.39 (high) \\
\hline Maintenance & 0.33 (low) & 0.35 (low) & 0.27 (low) & 0.49 (low) \\
\hline
\end{tabular}

The business and the recreational tourists differ significantly on their readiness to recommend the destination $\left(\chi^{2}=91.27, \mathrm{df}=1, \mathrm{p}<0.05\right)$. More recreational tourists are ready to recommend the destination than business tourists. The international and the domestic tourists also differ significantly on their readiness to recommend the destination $\left(\chi^{2}=12.63\right.$, $\left.\mathrm{df}=1, \mathrm{p}<0.05\right)$. More domestic tourists are ready to recommend the destination than international tourists. 
In order to identify the pattern of correlation between the destination attributes, factor analysis was performed as shown in Table 3 .

Table 3 Factor analysis of the destination attributes

Final Statistics:

\begin{tabular}{|l|c|c|c|c|c|}
\hline Variable & Communality & * Factor & Eigenvalue & Pct of Var & Cum Pet \\
\hline SAFED1 & 0.78034 & $* 1$ & 2.73907 & 30.4 & $30.4 \%$ \\
\hline SAFEN1 & 0.47899 & $* 2$ & 1.49867 & 16.7 & $47.1 \%$ \\
\hline TRANSPR1 & 0.17509 & $* 3$ & 1.04603 & 11.6 & $58.7 \%$ \\
\hline
\end{tabular}

Rotated Factor Matrix:

\begin{tabular}{|l|c|c|c|}
\hline & Factor 1 & Factor 2 & Factor 3 \\
\hline SAFED1 & -0.07479 & -0.01032 & 0.88014 \\
\hline SAFEN1 & -0.09133 & 0.38417 & 0.56839 \\
\hline TRANSPR1 & -0.04144 & 0.39206 & 0.14022 \\
\hline HOSPITA1 & 0.08635 & 0.77007 & 0.10745 \\
\hline C.HOTEL1 & 0.76488 & -0.10974 & 0.02753 \\
\hline C.MEALS1 & 0.76998 & 0.01042 & -0.19278 \\
\hline C.DRINK1 & 0.85463 & -0.18303 & 0.02237 \\
\hline C.TRANS1 & 0.76550 & 0.03962 & -0.09711 \\
\hline ATTR.MT1 & -0.20421 & 0.77208 & -0.10081 \\
\hline
\end{tabular}

Note: Variables Label

SAFEDI safety at day time

SAFEN1 safety at night

TRANSPR1 transportation and traffic problems

HOSPITA1 how tourist feels attended to in Lagos

C.HOTEL1 cost of hotel accommodation

C.MEALS1 cost of meals

C.DRINK1 cost of drinks

C.TRANS1 cost of transportation

ATTR.MT1 maintenance

Examination of the correlation among the destination attributes or variables reveals that there are significant overlaps among the variables as shown in Table 3. The 'Final Statistics' in the Table shows that 3 factors are extracted, and that, 58.7 per cent of the total variance has been explained. As shown by the 'Varimax Rotated Factor Matrix', the factor loadings reveal that 'cost of hotel accommodation', 'cost of meals', 'cost of drinks', and 'cost of transportation' are closely related, with large loadings of $0.76488,0.76998,0.85463$, and 0.76550 respectively. They form the 'Factor 1 ' that is denominated as 'cost of living'. The 
second factor (Factor 2) is formed through a correlation between 'hospitality', 'maintenance' and 'transportation and traffic problems'. Hospitality and maintenance have large loadings of 0.77007 and 0.77208 respectively, while, 'transportation and traffic problems' has a loading of 0.39206 . This factor is denominated as 'Services'. Although 'safety at night time' has a smaller loading of 0.38417 in this factor, it is excluded from the factor since 'safety' forms a separate factor (factor 3); 'Safety at day time ', and 'safety at night' form the Factor 3. They have large loadings of 0.88014 and 0.56839 respectively. This factor is denominated as 'personal safety'. The factor scores are used to represent the standardised values of the factors in each observation. They are used in the subsequent statistical analyses of the destination attributes.

In order to test the relationship between the destination attributes (factors 1,2 , and 3) and the business and recreational tourists' readiness to recommend the destination to others, Logistic Regression Analysis was applied as shown in the Tables $4 a$ and $4 b$.

Table 4a Logistic regression of business tourists' readiness for recommendation and the destination attributes (factors 1, 2, and 3)

Classification table for recommendation

\begin{tabular}{|l|c|c|c|c|}
\hline \multirow{2}{*}{\multicolumn{2}{|c|}{ Observed }} & \multicolumn{2}{c|}{ Predicted } & \multirow{2}{*}{ Percent Correct } \\
\cline { 2 - 5 } & 0.0000 & 1.0000 & \\
\cline { 2 - 5 } & 0 & 1 & $64.47 \%$ \\
\hline 0.0000 & 0 & 49 & 27 & $90.97 \%$ \\
\hline 1.0000 & 1 & 13 & 131 & $81.82 \%$ \\
\hline \multicolumn{3}{|c|}{ Overall } \\
\hline
\end{tabular}

Variables in the equation:

\begin{tabular}{|l|c|c|c|c|c|c|c|}
\hline Variable & B & S.E. & Wald & df & Sig & R & $\operatorname{Exp(B)}$ \\
\hline FACTOR1 & -0.2142 & 0.1568 & 1.8668 & 1 & 0.1718 & 0.0000 & 0.8072 \\
\hline FACTOR2 & 1.0670 & 0.1896 & 31.6738 & 1 & 0.0000 & 0.3235 & 2.9066 \\
\hline FACTOR3 & 0.5685 & 0.1653 & 11.8233 & 1 & 0.0006 & 0.1861 & 1.7657 \\
\hline Constant & 0.7745 & 0.1696 & 20.8581 & 1 & 0.0000 & & \\
\hline
\end{tabular}

Note: Total number of cases: 
Table 4b Logistic regression of recreational tourists' readiness for recommendation and the destination attributes (factors 1,2 , and 3)

Classification table for recommendation:

\begin{tabular}{|l|c|c|c|c|}
\hline \multirow{2}{*}{\multicolumn{2}{|c|}{ Observed }} & \multicolumn{2}{|c|}{ Predicted } & \multirow{2}{*}{ Percent Correct } \\
\cline { 2 - 5 } & 0.0000 & 1.0000 & $0.00 \%$ \\
\cline { 2 - 5 } & 0 & 1 & 18 & $100.00 \%$ \\
\hline 0.0000 & 0 & 0 & 126 & $87.50 \%$ \\
\hline 1.0000 & 1 & 0 & & \\
\hline \multicolumn{3}{|c|}{ Overall } \\
\hline
\end{tabular}

Variables in the equation:

\begin{tabular}{|l|c|c|c|c|c|c|c|}
\hline Variable & B & S.E. & Wald & df & Sig & R & $\operatorname{Exp(B)}$ \\
\hline FACTOR1 & -0.3200 & 0.1938 & 2.7273 & 1 & 0.0986 & -0.0819 & 0.7262 \\
\hline FACTOR2 & 0.3208 & 0.2884 & 1.2372 & 1 & 0.2660 & 0.0000 & 1.3782 \\
\hline FACTOR3 & 0.2521 & 0.2635 & 0.9150 & 1 & 0.3388 & 0.0000 & 1.2867 \\
\hline Constant & 2.0967 & 0.2883 & 52.8741 & 1 & 0.0000 & & \\
\hline
\end{tabular}

Note: Total number of cases:

Number of selected cases:

According to the Logistic Regression Analysis in Table 4a, the analyses indicate that 81.82 per cent of the result has been predicted correctly in the case of the business group. In the case of the recreational group, 87.50 per cent of the result has been predicted correctly (see Table 4b). More details of the results are presented below according to each Factor.

Factor 1 (cost of living):

As shown in Table 4a, the Logistic Regression Coefficient in the case of the business tourists indicates no statistical significance $(B=-0.2142, p>0.05)$. This means that, the business tourists' perception of the 'cost of living' during their stay in Lagos, does not influence their readiness or willingness to recommend this State as a tourist destination. The same also applies to the recreational tourists (see Table $4 b, B=-0.3200, p>0.05$ ). 
Factor 2 (hospitality, maintenance and transportation):

As shown in Table 4a, Factor 2 has a significant relationship with the readiness of the business tourists to recommend the destination to others $(B=1.0670, p<$ 0.05). This result further indicates that, on the one hand, the business tourists who perceived a high value of Factor 2, that is, a high level of hospitality and maintenance, and a low level of transportation and traffic problems, tend to recommend the destination to others (see also Table 2). On the other hand, it suggests that those who perceived a low value of Factor 2 (a low level of hospitality and maintenance, and a high level of transportation and traffic problems), tend to show no readiness for recommendation. Contrarily, Factor 2 has no significant relationship with the recreational tourists' readiness to recommend Lagos as a tourist destination (Table $4 b, B=0,3208, p>0,05$ ).

\section{Factor 3 (personal safety):}

As shown in Table 4a, 'personal safety' has a significant relationship with the readiness of the business tourists to recommend Lagos to others $(B=0.5685, p<$ 0.05 ). The results also suggest that those who perceived a high value of personal safety, would recommend the destination to others and those who perceived a low value of personal safety, would not recommend the destination. Contrary to that, personal safety has no significant relationship with the recreational tourists' readiness to recommend Lagos as a tourist destination (Table $4 b, B=0.2521, p$ $>0.05)$.

In order to test the relationship between the destination attributes (factors 1, 2, and 3) and the internationals and domestic tourists' readiness to recommend the destination to others, Logistic Regression Analysis was applied as shown in Table 5a and Table 5b.

Table 5a Logistic regression of international tourists' readiness for recommendation and the destination attributes (factors 1, 2, and 3)

Classification table for recommendation:

\begin{tabular}{|c|c|c|c|c|}
\hline & \multicolumn{2}{|c|}{ Predicted } & Percentage Correct \\
\hline \multicolumn{2}{|c|}{ Observed } & .0000 & 1.0000 & \\
\hline & .0000 & 36 & 22 & 62.1 \\
\hline & 1.0000 & 10 & 83 & 89.2 \\
\hline \multicolumn{3}{|c|}{ Overall } \\
\hline
\end{tabular}


Variables in the equation:

\begin{tabular}{|l|c|c|c|c|c|c|}
\hline & B & S.E. & Wald & df & Sig. & $\operatorname{Exp}(\mathbf{B})$ \\
\hline FACTOR1 &. .078 & .154 & .252 & 1 & .616 & .925 \\
\hline FACTOR2 & 1.124 & .229 & 24.073 & 1 & .000 & 3.078 \\
\hline FACTOR3 & .208 & .182 & 1.314 & 1 & .252 & 1.232 \\
\hline Constant & .741 & .207 & 12.777 & 1 & .000 & 2.099 \\
\hline
\end{tabular}

Note: Total number of cases: 154

Number of selected cases: 151

Missing cases: 3

Table 5b Logistic regression of domestic tourists' readiness for recommendation and the destination attributes (factors 1,2 , and 3)

Classification table for recommendation:

\begin{tabular}{|c|c|c|c|}
\hline & \multicolumn{2}{|c|}{ Predicted } & Percentage Correct \\
\hline Observed & .0000 & 1.0000 & \\
\hline .0000 & 0 & 36 & .0 \\
\hline 1.0000 & 0 & 176 & 100.0 \\
\hline \multicolumn{3}{|c|}{ Overall } & 83.0 \\
\hline
\end{tabular}

Variables in the equation:

\begin{tabular}{|l|c|c|c|c|c|c|}
\hline & B & S.E. & Wald & df & Sig. & $\operatorname{Exp(B)}$ \\
\hline FACTOR1 & -.283 & .179 & 2.498 & 1 & .114 & .754 \\
\hline FACTOR2 & .471 & .209 & 5.080 & 1 & .024 & 1.602 \\
\hline FACTOR3 & .539 & .196 & 7.552 & 1 & .006 & 1.714 \\
\hline Constant & 1.707 & .206 & 68.624 & 1 & .000 & 5.512 \\
\hline
\end{tabular}

Note: Total number of cases: 223

Number of selected cases: 212

Missing cases:

According to the Logistic Regression Analysis in Table 5a, the analyses indicate that 78.8 per cent of the result has been predicted correctly in the case of the international tourists. In the case of the domestic tourists, 83.0 per cent of the result has been predicted correctly (see Table 5b). More details of the results are presented below according to each Factor. 
Factor 1 (cost of living):

As shown in Tables 5a and 5b, the Logistic Regression Coefficients in both cases of the international and domestic tourists indicate no statistical

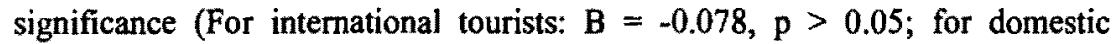
tourists: $B=-0.283, p>0.05$ ). This means that, both the international and domestic tourists' perceptions of the 'cost of living' during their stay in Lagos, do not influence their readiness or willingness to recommend this State as a tourist destination.

Factor 2 (hospitality, maintenance and transportation):

As shown in Table 5a, Factor 2 has a significant relationship with the readiness of the international tourists to recommend the destination to others $(B=1.124$, $p$ $<0.05$ ). This result further indicates that, on the one hand, the international tourists who perceived a high value of Factor 2, that is, a high level of hospitality and maintenance, and a low level of transportation and traffic problems, tend to recommend the destination to others. On the other hand, it suggests that those who perceived a low value of Factor 2 (a low level of hospitality and maintenance, and a high level of transportation and traffic problems), tend to show no readiness for recommendation.

Factor 2 has also a significant relationship with the domestic tourists' readiness to recommend Lagos as a tourist destination (Table $5 \mathrm{~b}, \mathrm{~B}=0.471, \mathrm{p}<0.05$ ). Therefore, the same thing applies to them as in the case of the international tourists.

Factor 3 (personal safety):

As shown in Table 5a, 'personal safety' has no significant relationship with the readiness of the international tourists to recommend Lagos to others $(B=0.208$, $p>0.05$ ). The results suggest that their value of personal safety do not influence their readiness to recommend the destination to others. Contrary to that, personal safety has a significant relationship with the domestic tourists' readiness to recommend Lagos as a tourist destination (Table $5 b, B=0.539, p<0.05$ ). The results also suggest that those who perceived a high value of personal safety, would recommend the destination to others and those who perceived a low value of personal safety, would not recommend the destination. 


\section{DISCUSSION}

The results of this study show that more recreational tourists are ready to recommend the destination than the business tourists. Also, more domestic tourists are ready to recommend the destination than the international tourists. Put differently, more business and more international tourists are not ready to recommend Lagos State as a tourist destination compared to their recreational and domestic counterparts (respectively). According to Horovitz (1990), a dissatisfied consumer communicates his or her dissatisfaction to an average of eleven persons, while a satisfied consumer communicates his or her satisfaction to an average of three persons. Demos (1992: 81-86) also holds that one dissatisfied consumer has more influence than the satisfied ones. This implies that the number of participants (in our study) who are not ready to recommend Lagos State as a tourism destination (33.6 per cent of the business tourists and 12.1 per cent of the recreational tourists; 16.8 per cent of the domestic tourists and 37.7 per cent of the international tourists), thereby expressing their dissatisfaction, would have a much higher adverse effect on tourism and the economy of the state than initially appears. As Balogun (1994) indicated, there is a decline in Nigeria's foreign exchange earnings. Thus, Lagos State needs to embark on extensive tourism awareness and tourism improvement measures to reduce (especially, business and international) tourists' dissatisfaction to the minimum.

Results also show that hospitality, maintenance of infrastructure and transportation/traffic problems (Factor 2) have a significant influence on the business tourists' - international as well as domestic - readiness to recommend the destination to others. That implies that if the above destination attributes do not meet the expectations of the three types of tourists, they would not recommend the destination to others. Thus, urgent measures must be taken by the Lagos State government and the tourism industries in the state to reduce the problems in the area of hospitality, maintenance and transport.

As Inskeep (1991) asserts, hospitality is one of the crucial tourist attractions and is essential for tourism development. In Nigeria and West Africa as a whole, high levels of hospitality have been one of the major attraction potentials of tourism (Burch, 1997: 23-27; Olokesusi, 1989; World Tourism Organisation, 1984). Similar to hospitality, transportation is recognised as one of the major infrastructural elements whose functionality is highly needed for successful tourism (Blank, 1989; Danaher \& Arweiler, 1997: 89-93; Feilmayr, 1996; Gunn, 1994; Inskeep, 1991; Mill \& Morrison, 1985; Steinbach, 1991; Steinbach et al., 1983; but, this infrastructure or service is among the most critical destination problems in tourism planning in the non-industrialised countries (Heraty, 1989: 
272-4). As one can see, the above result on Lagos State reflects Inskeep's opinion on hospitality, as well as Heraty's (1989: 272-4) view on transportation.

Transportation and traffic problems pose obstacles to tourism activities in Lagos since transportation often fails to function efficiently as the linkage between the tourists and their attractions. In fact, transportation and traffic problems have been a negative landmark in Lagos State. These are among the major daily problems in the lives of everyone in Lagos (see Balogun, 1993; Dickey, 1975).

Our study has also shown that personal safety (Factor 3 ) influences the business and domestic tourists' readiness to recommend the destination. This supports Inskeep's (1991) view that personal safety has a great impact and plays an important role in creating the image of a tourist destination. This may explain why tourism does not yet flourish in many parts of Africa, because of the high frequency of safety problems in this continent. It is then understandable when Arnold (1990), Boniface and Cooper (1989), Olekesusi (1989), Richter, (1992) and WTO $(1984,1997)$ see personal safety as one of the common problems of tourism in the countries of Africa. Personal safety problems may be seen as an outcome of political and economic problems and the resultant social problems like ineffective services of the police and other security forces result in disorderliness. These insufficient or ineffective services negatively affect the business and domestic tourists' feeling of safety and their readiness for recommendation of the destinations to others.

Considering the negative result with respect to safety at night (see Table 2), one may conclude that the police and other security forces in Lagos State are not efficient in their duties during those hours. Inefficiency of the security forces may even be worse in Lagos since its federal capital status was transferred to Abuja (in 1990). This transfer may mean a reduction of security, law and order especially at night, since the federal government's attention and presence have been partly withdrawn, leaving law and order to the State government. Feelings of insecurity at night may also be a result of the socio-economic problems in Nigeria as a whole. There is high social instability (especially among the youths, school leavers and graduates) caused by 'scarcity' due to the economic recession in the country as a whole. According to Balogun (1994), there is, among others, a decline in Nigeria's foreign exchange earnings, accumulation of arrears of trade debts, drastic diminishing of salaried employment and a rapid decline in the Gross National Product. There are few jobs for millions of applicants and people migrate within and outside the country in search of livelihoods (Nigerian Economic Review, 1993). Migration to Lagos as the main national metropolitan city therefore increases contributing to crime of various kinds, for example, robbery, fraud and corruption. This social malady of Lagos no doubt would 
prevent many business and domestic tourists from recommending the destination to others.

Cost of living (Factor 1) does not have a significant relationship with the readiness of both business, recreational, and domestic tourists to recommend the destination. The case of the business tourists seems to be understandable, since their travel expenses, are usually covered by their firms. The weak Nigerian currency (1 Naira was about 130 US dollars a the time of the research), may have made the international tourists who normally come with harder currencies less sensitive to the high cost of living. With reference to the recreational and domestic tourists, the explanation may also be that the perception of 'high cost' does not necessarily entail having spent 'much'. Rather, it may be that the awareness of the high cost of living in Lagos motivated some tourists to seek alternative ways of avoiding the high cost of living. For example, a recreational or domestic tourist who actually sees Lagos as being expensive may organise and stay with a friend or a relative to minimise the expenses. Nevertheless, 'cost control measures' should be proposed in concomitance with high quality services in Lagos. This is vital, since the targets for destination planning and marketing should be to achieve a high tourist satisfaction in order to win their loyalty as well as their readiness for further recommendation of the destination to the potential tourists.

One would expect a significant relationship between Factor 2 (hospitality, maintenance and transportation) and the recreational tourists' readiness to recommend the destination as it is the case with the other three types of tourists, but the opposite is the case. However, the negative effects transportation, for example, would be more pronounced on a business (intermational or domestic) tourist who misses his business appointment than it would be on a recreational tourist. This does not mean that the fulfilment of the recreational tourist's daily activity schedule may not be as important as that of the business tourists; rather, it is assumed that the recreational tourists may be more flexible in this instance.

According to the results of the study, personal safety has no influence on the recreational and international tourists readiness to recommend the destination. This may be because recreational tourists have the free choice of destinations for their recreational activities and therefore, may not willingly choose an unsafe destination site for their holiday. The international tourists may also be better informed on safety measures before travelling to Nigeria than the domestic tourists. 


\section{LIMITATIONS OF STUDY}

This study did not investigate beyond the 'on-site experiences' of the tourists. Although investigations that may capture the tourists' readiness to recommend Lagos State at the time the tourists have gone back home may be very expensive, it may give some insight into the tourists' post-travel-perception of the State and their readiness to recommend. Consumers' perception of a service is a continuous process and could be assessed in any phase of the travel experience. Thus, further research on tourists' readiness for recommendation of Lagos State as a tourist destination to others, based on the last phase of the travel experience, that is, after the visit to Lagos, is strongly suggested. The possible effects of age, nationality and 'first time' and 'repeat' visitors on their readiness to recommend Lagos State to others have not been investigated. Further studies on tourists' impression and readiness to recommend other destinations in Nigeria and West Africa as a whole are also strongly suggested. The distributions of the sample population (business versus recreational tourists, domestic versus international tourists), as well as that of the respondents in the different sites, are unbalanced. This may have affected the results of the study.

\section{CONCLUSION AND RECOMMENDATIONS}

Stringent measures need to be taken to improve Lagos State as a tourist destination, especially in the area of hospitality, maintenance and transportation, and personal safety. Therefore, the following are suggested:

First, transportation and traffic hindrances (e.g., traffic jams, go-slows, safety lapses, snatching and pickpocketing) should be dealt with in the State. This should be done through the location and concentration of the tourist facilities outside the busy business centres of Lagos. For example, a recreational resort centre ('Badagry Resort') should be planned in Badagry in the west wing of Lagos State, and another one ('Ibeju/Lekki Resort') in the east wing. These areas are a distance from the congested centre of Lagos. Direct connection roads should be constructed to link up the recreational resorts with the international airport and other major entry ports to Lagos State.

Transportation should be wholly or partly taken over by the State Government. This will entail detailed planning of shuttle bus services to link the holiday resorts with the airport and main Lagos, as well as other tourist attractions. Regular bus services and prompt arrival of buses at the bus stops involve accurate planning and good execution. Taxi services as well as private transport services organised by travel agencies should also be encouraged. 
The unique potential of the Atlantic ocean and waterways in Lagos should be exploited for ferry and boat transportation of the tourists between the resorts in order to minimise transportation problems. Pollution due to such transportation should however be avoided in the planning. This transportation should give the tourists the opportunity to have a round trip sightseeing tour over land and sea, and may also serve as one of the major tourist attractions in Lagos.

Second, measures aimed at improving personal safety in the state should be instituted. When transport is organised for tourists and housing designed to guarantee safety, the problem of safety will be solved to some extent. The planned resorts should have functional police stations with staff specially trained on the need and behaviour of the tourists in order to avoid police nuisance. Constant police patrol is recommended, particularly at night. Hawkers should be cleared from the streets and the quality of the commodities sold in the resort areas should be controlled to prevent the sale of stolen goods. Functional banking services should be made available to cope with the needs of tourists. This will avoid the safety hazard of carrying large sums of cash and therefore reduce the risk of being attacked, or even the fear of being attacked.

Third, people employed in the tourism industry should be well-trained in hospitality. Finally, more money should be invested in maintaining tourist infrastructure in the State; a maintenance culture should be developed and maintained in the State.

\section{REFERENCES}

1 ADEPOJU, E.A. (1990) Tourism and Recreational Facilities of Lagos Coastal Landscape (Social, Political and Economic implications), A paper presented at the Department of Architecture, University of Lagos, Nigeria.

2 AJAYI, B. (1998) "Property: Lagos Sheds Dirty City Toga", Tell: Nigeria's Independent Weekly Magazine, 33 (August): 1-3.

3 ARNOLD, K. (1990) "Fremdenverkehrsgeographie, Teil D, Die Aussereuropaeischen Fremdenverkehrsraeume" A working paper, part D, University of Economics, Vienna.

4 BAHIA, K. \& PAULIN, M. (2000) "Reconciliation Literature About Client Satisfaction and Perceived Services Quality." Joumal of Professional Services Marketing, 21(2): 27-42.

5 BALOGUN, O. (1986) "Physical Planning Administration in Lagos State of Nigeria", An unpublished Dissertation, Department Urban and Regional Planning, Faculty of Environmental Studies, University of Ibadan, Nigeria. 
6 BALOGUN, O. (1993) "Road Congestion and Traffic Composition in Lagos Metropolitan Area of Nigeria: Analysis and Solutions", An unpublished Dissertation, Department of Transportation Planning, University of Technology, Vienna.

7 BALOGUN, S.K. (1994) Basic Concepts in Society Government and Economy, Ibadan: Sam Bookman.

8 BARLOW, J. \& MOLLER, C. (1996) Eine Beschwerde ist ein Geschenk der Kunde als Consultant, Vienna: Wirtschaftsverlag Carl Ueberreuter.

9 BARSKY, J.D. \& LABAGH R. (1992) "A Strategy for Customer Satisfaction", Cornell Hotel and Restaurant Administration Quarterly, (October): 32-40.

10 BLANK, U. (1989) The Community Tourism Industry Imperative: The Necessity, the Opportunities, It's Potential, State College, PA: Venture.

11 BONIFACE, B.G. \& COOPER, C.P. (1989) The Geography of Travel and Tourism, London: Heinemann.

12 BRANDY, M.K. \& ROBERTSON, C.J. (2001) "Searching for a Consensus on the Antecedent Role of Service Quality and Satisfaction." Journal of Business Research, 51(1): 53-61.

13 BURCH, B. (1997) "Ecotourist's Paradise", African Business, 225 (October): 23-27.

14 DANAHER, P.J. \& ARWEILER, N. (1997) "Consumer Satisfaction in the Tourism Industry: A Case Study of Visitors to New Zealand", Travel and Tourism Research, 35 (Summer): 89-93.

15 DEMOS, E. (1992) "Concern for Safety: A Potential Problem in the Tourist Industry". Journal of Travel and Tourism Marketing, 1 (1): 81-86.

16 DICKEY, J. (1975) Metropolitan Transportation Planning, Washington D.C: Scripta Book.

17 DISNEY, J. (1999) "Customer Satisfaction and Loyalty: the Critical Elements of Service Quality", Total Quality Management, 10(4/5): 491-8.

18 FEILMAYR, W. (1996) Raeumliche Fremdenverkehrsanalyse und Fremdenverkehrsplanung, Vienna: Department of Urban and Regional Research, University of Technology.

19 GUNN, C.A. (1994) Tourism Planning - Basics - Concepts - Cases, Washington D.C: Taylor \& Francis.

20 HERATY, M.J. (1989) "Tourism Transport-Implementations for Developing Countries", Tourism Management, 10(4): 272-4.

21 HERRMANN, A. \& HUBER, F. (2000) "Market-Driven Product and Service Design: Bridging the Gap Between Customer Needs, Quality Management, and Customer Satisfaction", Intemational Journal of Production Economics, 66(1): 77-97.

22 HOROVITZ, J. (1990) How to Win Customers, Using Service for a Competitive Edge, United Kingdom: Longman. 
23 INSKEEP, E. (1991) Tourism Planning - An Integrated and Sustainable Development Approach, New York: Van Nostrand Reinhold.

24 LASSAR, W.M., MANOLIS, C. \& WINSOR, R.D. (2000) "Service Quality Perspectives and Satisfaction in Private Banking", International Journal of Bank Marketing, 18(4/5): 181-200.

25 LEE, H., LEE, Y. \& YOO, D. (2000) "The determinants of Perceived Service Quality and its Relationship with Satisfaction." Journal of Service Marketing, 14(2/3): 217-32.

26 MILL, R.C. \& MORRISON A.M. (1985) The Tourism System. Englewood Cliffs, NJ: Prentice-Hall.

27 NIGERIAN ECONOMIC REVIEW (1993) Economic Statistics and Graphs, Lagos: John West.

28 ODUTAYO, K. (1986) "Tourism and the Nigerian Economy". The Guardian Press, Lagos, 12th June, 11.

29 OLOKESUSI, F. (1989) Tourism Development in Nigeria - a study of Bauchi and Ogun States, Ibadan: Nigerian Institute of Social and Economic Research.

30 OLUKOYA S. (1989) A Study on Tourism Development at the Lagos Beaches: A Pilot Study of Tarqua Bay, A paper presented at the Department of Architecture, University of Lagos, Nigeria.

3) PERTERSON, R. \& WILSON, W.R. (1992) "Measuring Customer Satisfaction: Fact and Artefact", Journal of the Academy of Marketing Science, 20 (1): 61-71.

32 RICHTER, L.K. (1992) Political Instability and Tourism in the Third World, in Tourism and the less developed countries. London: Belhaven Press.

33 SMOLTCZYK, A. (1997) "Lagos, Ueberleben im Moloch von Afrika". GEO Magazine, 3 (March): 54-71.

34 STEINBACH, J. (1991) Wandel von Angebot und Nachfrage im Fremdenverkehr: Neue Tendenzen im Tourismus, Wandeln sich Urlaubziele und Urlaubsaktivitaeten?, Muenchen: Geobuch.

35 STEINBACH, J., FEILMAYR W., HANG H., \& STUDENTISCHE, M. (1983) Regionalanalysen im Land Salzburg. Vienna: Department of Urban and Regional Research, University of Technology Vienna.

36 SURESHCHANDAR, G. S., RAJENDRAN, C., \& KAMALANABHAN, T.J. (2001) "Customer Perceptions of Service Quality: A Critique", Total Quality Management, 12(1): 111-125.

37 UKPANAH, S.J. (1990) "Nigeria's Tourism Resources and Potentials to be Harnessed", Tourism, l (1): 12-18.

38 VAVRA, T.G. (1997) Improving your Measurement of Customer Satisfaction: a Guide to Creating, Conducting, Analysing, and Reporting Customer Satisfaction Measurement Programmes. Wisconsin: ASQ Quality Press. 
39 WORLD TOURISM ORGANISATION (1984) Regional Conference on Intra-African Tourism Co-operation, Niamey: World Tourism Organisation.

40 WORLD TOURISM ORGANISATION (1997) Tourism Market Trends Africa, Madrid: World Tourism Organisation.

41 ZEITHAML, V., BERRY, L. \& PARASURAMAN, A. (1996) "The Behavioural Consequences of Service Quality", Journal of Marketing, 60: $31-46$. 